No. 4567 May 11, 1957

Boultbee took up his appointment as keeper of the Queen Victoria Museum in November. He states that the existing building is entirely unsuitable for museum purposes and that the only possible solution is to rebuild. The problem is fully appreciated by the Trustees, and negotiations with the City of Salisbury for a site in the new Civic Centre are in progress.

\section{Field Studies Council Courses}

The Field Studies Council is to hold a course on "Weather and Flight" at Preston Montford Field Centre, Montford Bridge, near Shrewsbury, during July $3-10$. This course, which is to be directed by' Dr. R. S. Scorer, lecturer in meteorology in the Imperial College of Science and Technology, London, is designed particularly for pilots of gliders and other aircraft to whom observation and interpretation of weather are of practical importance; but it; should also be of interest and value to ornithologists, entomologists and others concerned with the effect of weather on animal flight. Elementary meteorology and aerodynamics will form the basis of the course, for which a knowledge of advanced mathematics is not necessary. The emphasis of the course is upon observation out of doors, and particular attention will be paid to weather photography and the recognition of clouds. It is hoped to arrange a visit to a gliding club where there will be opportunity to take to the air.

The Field Studies Council, in association with the Royal Meteorological Society, has also arranged a Short Vacation Course in Meteorology, to be held at Malham Tarn Field Centre, near Settle, Yorkshire, during August 21-28. The course will be directed by C. D. Ovey, lecturer in geography in the University of Cambridge, and by Dr. R. S. Scorer. The emphasis will be on practical aspects of meteorology, and previous experience is not essential. Forms of application and further particulars about the courses can be obtained from the Wardens of the respective Field Centres.

\section{Fishery Research Training Grants}

THE Development Commissioners, in association with the Ministry of Agriculture, Fisheries and Food and the Scottish Home Department, are to award two-or if there are sufficient applicants of exceptional merit three-postgraduate training grants in fishery research tenable from October. These training grants are intended to enable selected candidates to undergo a specified course of training to fit them for the investigation of problems in marine or freshwater science. The course will not normally enable the holder of an award to qualify at the same time for a higher degree, but the Commissioners would consider applications from candidates for permission to register for a higher degree in circumstances where this seems likely to be consistent with the requirements of the approved fishery research training programme. The training which students will receive should fit them for employment either in the Fishery Research Service of the Ministry of Agriculture, Fisheries and Food and the Scottish Home Depart. ment or in a marine or freshwater biological research institution. Candidates must be British subjects and graduates with honours in science or possess equivalent qualifications. Further details and forms of application, to be returned by May 27, can be obtained from the Secretary, Development Commission, 3 Dean's Yard, Westminster, London, S.W.1.

\section{Zoological Nomenclature}

THE International Commission on Zoological Nomenclature gives notice that as from September 29,1957 , it will start voting on the following cases involving the possible use of its plenary powers for the purposes specified. Full details were published on March 29 in the Bulletin of Zoological Nomenclature (13, Double-Part 2/3 and Part 4): (1) Viviparidae Gray (J. E.), 1847, validation and counter-proposal for suppression of Viviparus Montfort, 1810 (Cl. Gastropoda); (2) mississippiensis (emend. of mississipiensis), validation of, as specific name for North American alligator (Cl. Reptilia); (3) Muntiacinae Pocock, 1923, and Odobenidae Allen (J. A.), 1880, validation of for the barking deer and walrus respectively (Cl. Mammalia) ; (4) Dictyoploca Jordan, 1911 , validation (Cl. Insecta, Order Lepidoptera); (5) Staphylinus Linnæus, 1758, designation of Stophylinus erythropterus (emend of erytropterus) Linnæus, 1758, as type species of (Cl. Insecta, Order Coleoptera); (6) Anopheles Meigen, 1818, designation of type species for (Cl. Insecta, Order Diptera); (7) picto Walckenæer, 1802 (Aranea) and Theridium (emend. of Theridion) Walckenaer, 1805, validation (Cl. Arachnida); (8) Vespertilio murinus Linnæus, 1758, type species of Vespertilio Linnæus, 1758, clarification of interpretation of (Cl. Mammalia); (9) Toxorhynchites Theobald, July 1901, validation (Cl. Insecta, Order Diptera); (10) truncatula Bruguière [1792] (Bulla), interpretation of and umbilicata Montagu, 1803 (Bulla) validation (Cl. Gastropoda). Comments should be sent as soon as possible and in duplicate to Francis Hemming, Secretary to the Commission, 28 Park Village East, Regent's Park, London, N.W.1.

\section{National Institute of Agricultural Botany}

A RECENT issue of the Journal of the National Institute of Agricultural Botany (7, No. 3; 1957) contains reports on trials of winter wheats, spring oats, spring barleys, first early potatoes, sugar beet, lucerne and winter cauliflower which demonstrate how carefully the varieties are studied before recommendations are made. The question of impurities in the wheat variety 'Yeoman' is discussed by A. F. Kelly, who concludes that during the period 1948-53 mutation of one or more characters has occurred, although out-pollination may be responsible for some of the variation. F. L. Squibbs describes the characters of 21 varieties of dwarf beans which have appeared in British catalogues between 1950 and 1953 , and a $\mathrm{key}$, including 28 varieties previously described, incorporates 48 types, with illustrations of the seeds of each. The long series of lucerne strain trials bring out clearly the fact that yield is influenced by season and management more than by variety. Nevertheless, two strains of the earlier typo 'Chartrainvilliers' and 'Du Puits' showed consistent superiority in yield and agronomic behaviour over the other strains in these trials. The report records that $a$ further edition of "Varieties of Potatoes and their Synonyms" has been prepared, and the typescript is available for reference in the library of the Institute.

\section{Soils and Manures for Fruit}

For profitable fruit-growing, the selection of the right type of soil is as essential as good management and proper manurial treatment. Knowledge of the basic nutrient requirements of fruit trees is relatively 